This item was submitted to Loughborough's Research Repository by the author.

Items in Figshare are protected by copyright, with all rights reserved, unless otherwise indicated.

\title{
Novel membrane emulsification method of producing highly uniform silica particles using inexpensive silica sources
}

PLEASE CITE THE PUBLISHED VERSION

http://dx.doi.org/10.1007/978-3-642-28974-3_2

PUBLISHER

(C) Springer Verlag

VERSION

AM (Accepted Manuscript)

LICENCE

CC BY-NC-ND 4.0

\section{REPOSITORY RECORD}

Dragosavac, Marijana M., Goran T. Vladisavljevic, R.G. Holdich, and Michael T. Stillwell. 2012. "Novel Membrane Emulsification Method of Producing Highly Uniform Silica Particles Using Inexpensive Silica Sources". figshare. https://hdl.handle.net/2134/9366. 
This item was submitted to Loughborough's Institutional Repository (https://dspace.lboro.ac.uk/) by the author and is made available under the following Creative Commons Licence conditions.

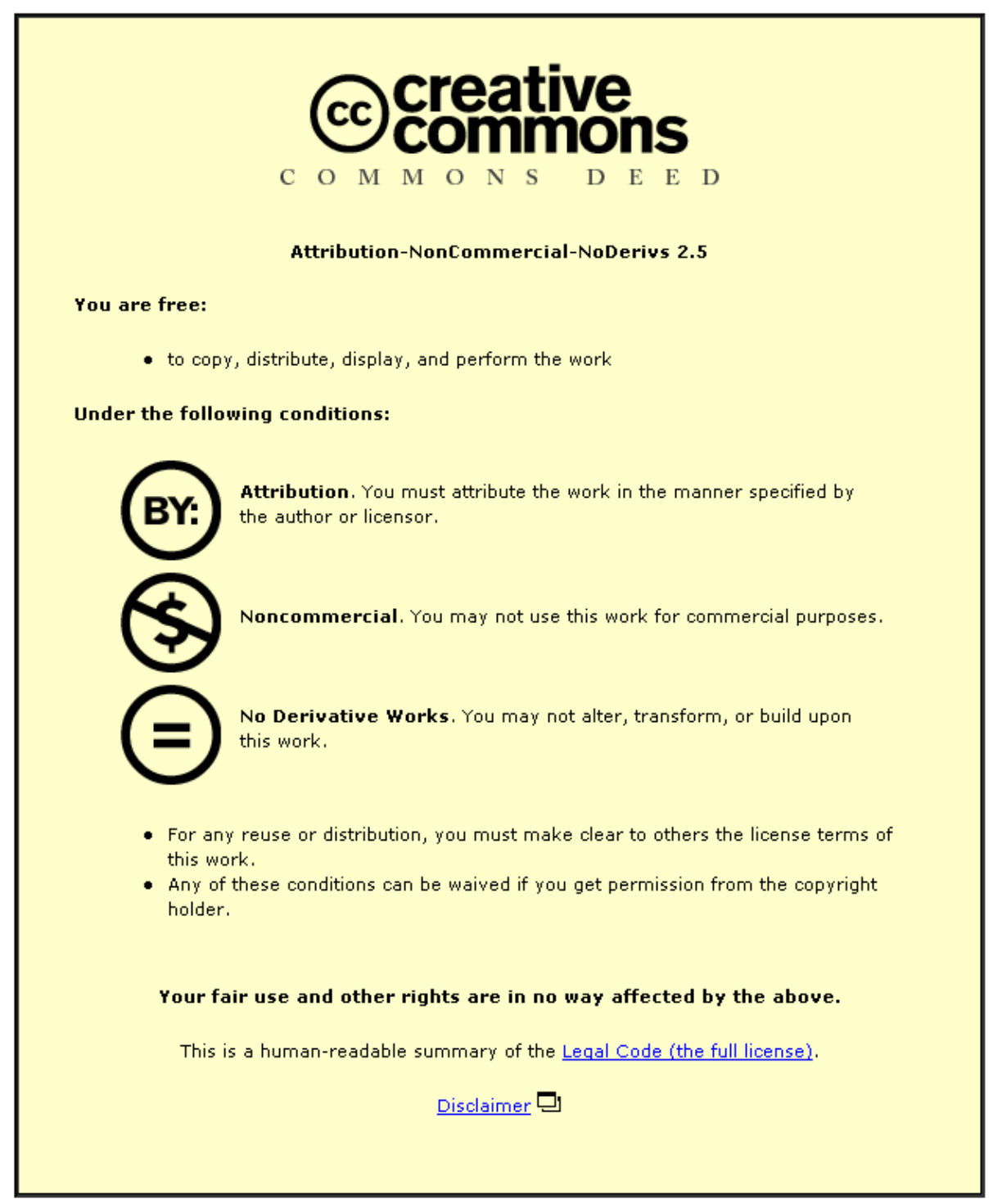

For the full text of this licence, please go to: http://creativecommons.org/licenses/by-nc-nd/2.5/ 


\title{
Novel membrane emulsification method of producing highly uniform silica particles using inexpensive silica sources
}

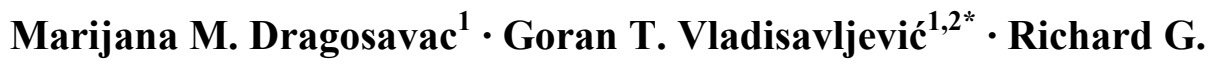 \\ Holdich $^{1,3} \cdot$ Michael T. Stillwell ${ }^{3}$ \\ ${ }^{1}$ Chemical Engineering Department, Loughborough University, Loughborough, Leicestershire \\ LE11 3TU, UK; ${ }^{2}$ Vinča Institute of Nuclear Sciences, PO Box 522, Belgrade, Serbia, ${ }^{3}$ Micropore \\ Technologies Ltd., Hatton, Derbyshire, DE65 5DU, UK
}

\begin{abstract}
A membrane emulsification method for production of monodispersed silica-based ion exchange particles through water-in-oil emulsion route is developed. A hydrophobic microsieve membrane with $15 \mu \mathrm{m}$ pore size and $200 \mu \mathrm{m}$ pore spacing was used to produce droplets, with a mean size between 65 and $240 \mu \mathrm{m}$ containing acidified sodium silicate solution (with 4 and $6 \% \mathrm{wt} . \mathrm{SiO}_{2}$ ) in kerosene. After drying, the final silica particles had a mean size in the range between 30 and 70 $\mu \mathrm{m}$. Coefficient of variation for both the droplets and particles did not exceed $35 \%$. The most uniform particles had a mean diameter of $40 \mu \mathrm{m}$ and coefficient of variation of $17 \%$. The particles were functionalised with 3-aminopropyltrimethoxysilane and used for chemisorption of $\mathrm{Cu}$ (II) from an aqueous solution of $\mathrm{CuSO}_{4}$ in a continuous flow stirred cell with slotted pore microfiltration membrane. Functionalised silica particles showed a higher binding affinity toward $\mathrm{Cu}(\mathrm{II})$ than non-treated silica particles.
\end{abstract}

Key words Membrane emulsification $\cdot$ Silica particles $\cdot$ Ion-exchange $\cdot$ Microfiltration • monodisperse particles $\cdot$ Functionalised silica gel

\section{Introduction}

There has been an increasing interest in the production of functionalised porous silica microspheres for use in analytical, preparative, and ion exchange columns, requiring particle diameters greater than $1 \mu \mathrm{m}$. A control of particle size and internal microstructure of silica particles is critically important in ion exchange, biochemical sensing [1], drug delivery [2], catalysis [3], and chromatography. Silica particles can be fabricated from organic silicon precursors, e.g. siliciumalkoxide [4] or inorganic materials, such as silicate solutions [5]. In the latter case, acidified sodium silicate solution is dispersed in an organic phase to form water-in-oil (W/O) emulsion [5] or atomized in air [6]. Silicic acid formed by acidification of sodium silicate immediately undergoes spontaneous

* Corr. Author: Goran Vladisavljević, e-mail: G.Vladisavljevic@lboro.ac.uk 
condensation polymerisation which progresses within the dispersed droplets, eventually leading to the formation of branched polymer with $-\mathrm{Si}-\mathrm{O}-\mathrm{Si}-$ bonds. Upon drying the formed silica hydrogel shrinks to xerogel. A surfactant can be dissolved in the silica solution to additionally tailor the internal gel structure (surfactant templating) [7]. This paper reports a novel $\mathrm{W} / \mathrm{O}$ emulsion route based on using microsieve-type membrane to prepare porous silica microspheres with a controllable size between 30 and $70 \mu \mathrm{m}$. To the best of our knowledge, membrane emulsification has only been used for fabrication of silica particles up to $3 \mu \mathrm{m}$ in size and only inorganic membranes were used in this application [8-11].

After functionalisation, the produced silica particles have been used as ion-exchange particles for removal of copper from an aqueous solution. Copper(II) is often used as a model cation for investigation of performance of ion exchangers. In addition, copper is widely present in industrial wastewaters and its disposal represents a big environmental threat, since it can induce severe health problems. Classical techniques for removal of copper from waste waters are flotation, chemical precipitation, and ion exchange with organic resins, such as sulfonated poly(styrene-co-divinylbenzene) resins [12]. In this work, new inorganic ion-exchange particles have been fabricated and tested for copper removal.

\section{Experimental}

Preparation of $\mathbf{W} / O$ emulsion. The dispersed phase was prepared by dripping sodium silicate solution, containing 10 or $15 \mathrm{wt} \% \mathrm{SiO}_{2}$, into $1 \mathrm{M} \mathrm{H}_{2} \mathrm{SO}_{4}$ under vigorous stirring until $\mathrm{pH}$ of 3.5 was achieved. The continuous phase was $5 \mathrm{wt} \%$ Span 80 in low odour kerosene (both supplied by Sigma Aldrich, UK). Emulsification was performed using a Micropore Technologies Ltd. Dispersion Cell (Figure 1a) equipped with a hydrophobic nickel membrane with $15 \mu \mathrm{m}$ pore size, $200 \mu \mathrm{m}$ spacing between the pores and $8.5 \mathrm{~cm}^{2}$ effective membrane area. The cell was filled with $100 \mathrm{ml}$ of continuous phase and $10 \mathrm{ml}$ of dispersed phase was injected at constant controllable rate using a Harvard Apparatus model 11 Plus syringe pump.

Production of silica particles. The resultant $\mathrm{W} / \mathrm{O}$ emulsion was transferred to a beaker, diluted with kerosene and continuously stirred until the hydrogel was formed. Beside the spherical silica particles, needle shapes of silica were also created. To filter them out, a microfiltration cell with slotted pore membrane was used. The membrane with an effective membrane area of $8.5 \mathrm{~cm}^{2}$ was provided by Micropore Technologies Ltd. Slots were $4 \mu \mathrm{m}$ wide and $250 \mu \mathrm{m}$ long enabling that even the smallest silica particles were maintained above the membrane. No spherical particles were observed in the filtrate and 
the amount of needle-like silica was less than $2 \%$ of the total particle mass being filtered. After removal of non-spherical silica, the particles were washed with at least $250 \mathrm{ml}$ of acetone followed by water washing to remove Span 80 and kerosene. After that, the particles were dried at room temperature and calcined at $550^{\circ} \mathrm{C}$ with a ramp step of $20^{\circ} \mathrm{C}$ $\min ^{-1}$ for 6 hours. Specific surface area of calcined silica particles was determined by the adsorption of nitrogen gas using Micromeritics ASAP 2020 [13].

Functionalisation of calcined silica particles and combined microfiltration and ion exchange. $10 \mathrm{~g}$ of calcined silica particles, with a specific surface area of $360 \mathrm{~m}^{2} \mathrm{~g}^{-1}$ was first washed with a mixture of nitric and hydrochloric acid in a ratio of $1: 3$ for $2 \mathrm{~h}$ in order to remove possible metal impurities. The particles were then filtered, dried in a vacuum at $200{ }^{\circ} \mathrm{C}$, and refluxed in a mixture of $80 \mathrm{ml}$ of toluene and $10 \mathrm{ml}$ of 3aminopropyltrimethoxysilane for $24 \mathrm{~h}$. After that, the particles were collected by filtration, washed with ethanol and then transferred to a Soxhlet extractor and washed with toluene for $24 \mathrm{~h}$, to eliminate possible traces of 3-aminopropyltrimethoxysilane. According to Lam et al. [14] silica functionalised with 3-aminopropyltrimethoxysilane is capable of adsorbing copper ions from solutions. Combined microfiltration and ion exchange was carried out at room temperature in a continuous flow stirred cell (Figure 1b) provided by Micropore Technologies Ltd. A metal membrane with $8 \times 400 \mu \mathrm{m}$ slots was fitted to the bottom of the cell. This slot width was fine enough to keep all particles in the cell. An aqueous solution of $\mathrm{CuSO}_{4}$ containing $10 \mathrm{~g} \mathrm{~cm}^{-3} \mathrm{Cu}$ (II) was continuously delivered to the cell at a constant flow rate of $8 \mathrm{ml} \mathrm{min}^{-1} .10 \mathrm{ml}$ samples of the effluent stream were taken at regular time intervals to determine $\mathrm{Cu}$ (II) concentration using an Atomic Absorbance Spectrophotometer (Spectra AA-200 Varian).

(a)

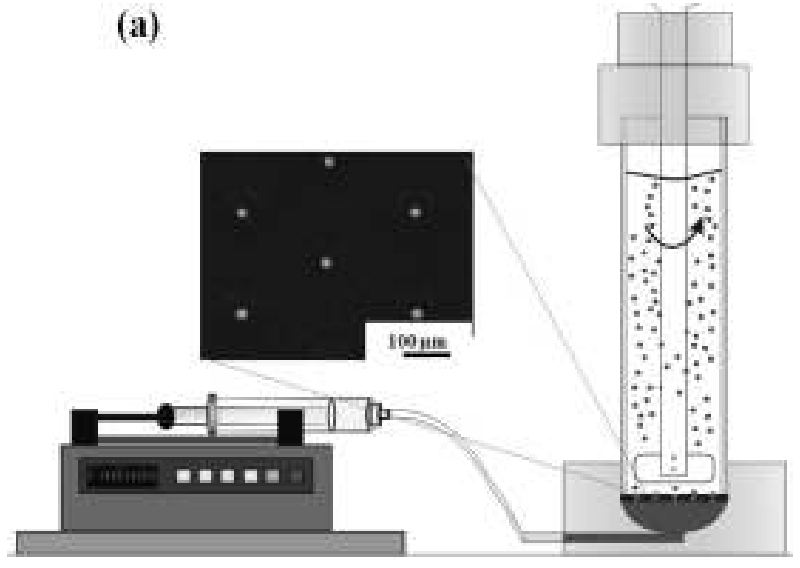

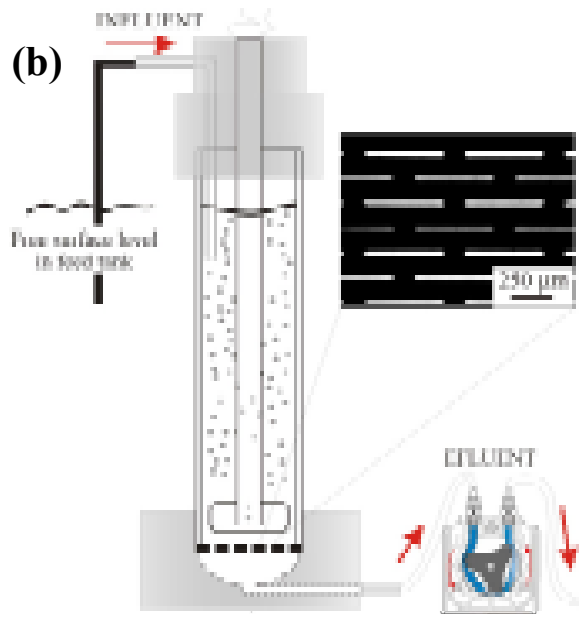

Figure 1 Schematic illustration of: (a) Dispersion Cell containing a paddle stirrer above a disk membrane with cylindrical $15 \mu \mathrm{m}$ pores used for membrane emulsification and (b) microfiltration system with slotted pore membrane used for combined microfiltration and ion exchange [12]. 


\section{Production of silica gel using membrane emulsification}

Figure 2 illustrates the effect of paddle rotation speed and flow rate of the dispersed phase on the droplet size of the $\mathrm{W} / \mathrm{O}$ emulsions produced. An increase of the rotation speed increases the shear stress on the membrane surface and the droplet formation time shortens, therefore, the smaller droplets are produced. The force balance model based on average shear stress [15] provided a good prediction of the droplet size for a very low flux of $1 \mathrm{~L} \mathrm{~m}^{-2} \mathrm{~h}^{-1}$. The parameters used for modeling are provided elsewhere [15]. Droplets produced using the higher injection rate are larger than the ones produced at lower injection rate and do not fit the model curve. Two explanations of this phenomenon are possible. First, the model does not take into consideration a dispersed phase inflow during the necking time. The detachment of the droplet is not instantaneous but requires a finite time, the necking time [16], during which an additional amount of dispersed phase flows into the droplet. Secondly, the model calculations are made using the equilibrium interfacial tension $\left(2.7 \mathrm{mN} \mathrm{m}^{-1}\right)$ which is lower than the actual interfacial tension during drop formation. It should be noted that the interfacial tension if no surfactant is present is $16 \mathrm{mN} \mathrm{m}^{-1}$ and during drop generation the liquid/liquid interface is not fully saturated with surfactant molecules. The produced droplets were stirred in a beaker in order to allow gelling and formation of a hydrogel. Once gelled, the hydrogel particles were dried to form a xerogel. Figure 3 illustrates the shrinkage of the dispersed phase droplets during their transformation into silica gel particles. During condensation polymerization the droplets will shrink due to water loss as the hydrogel is formed. The hydrogel particles were left to dry for several days at room temperature. During this drying stage liquid present in the pores is removed, the structure compresses and the porosity is reduced by the surface tension forces as the liquid is removed leaving dried silica particles (xerogel). Drying at room temperature was followed by calcination, but further shrinkage of the dried silica particles was not observed. The size of final silica particles was found to be 2.3 times smaller than the initial droplet size. However, the particles are still significantly bigger than would be predicted by a mass balance of the silica used in their formation. It can be explained by a significant amount of internal porosity, which is $88 \%$ and $64 \%$ for the hydrogel and xerogel particles, respectively. The coefficient of variation $(\mathrm{CV})$ for xerogel particles was below $31 \%$ and was minimal (17\%) for the particle diameter of 40 $\mu \mathrm{m}$. 


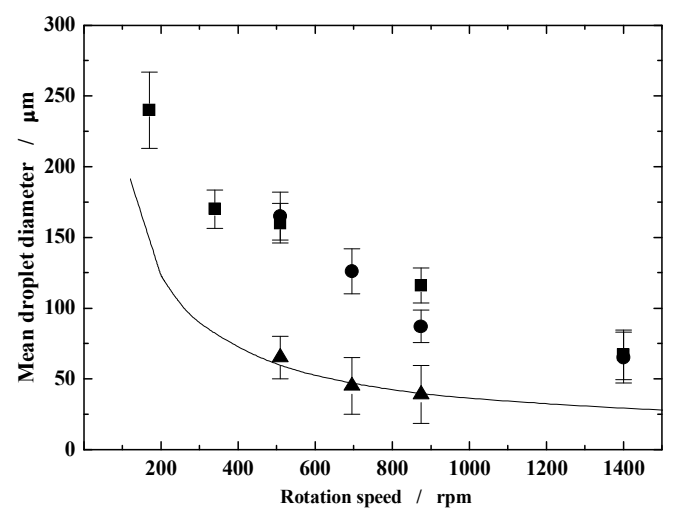

Figure 2 Droplet diameters of produced W/O emulsions as a function of rotation speed. Line represents the model prediction valid at low injection rates [15]. Dispersed phase: (ロ) Sodium silicate with $6 \mathrm{wt} \% \mathrm{SiO}_{2}$ in $1 \mathrm{M} \mathrm{H}_{2} \mathrm{SO}_{4}$ injected at $350 \mathrm{~L} \mathrm{~m}^{-2} \mathrm{~h}^{-1}$. (•) Sodium silicate with $4 \mathrm{wt} \%$ $\mathrm{SiO}_{2}$ in $1 \mathrm{M} \mathrm{H}_{2} \mathrm{SO}_{4}$ injected at $350 \mathrm{~L} \mathrm{~m}^{-2} \mathrm{~h}^{-1}$. (ム) Sodium silicate with $6 \mathrm{wt} \% \mathrm{SiO}_{2}$ in distilled water injected at $1 \mathrm{~L} \mathrm{~m}^{-2} \mathrm{~h}^{-1}$. Error bars in the figure represent one standard deviation $(\sigma=\mathrm{CV} \times \mathrm{d} / 100)$ from the mean value.

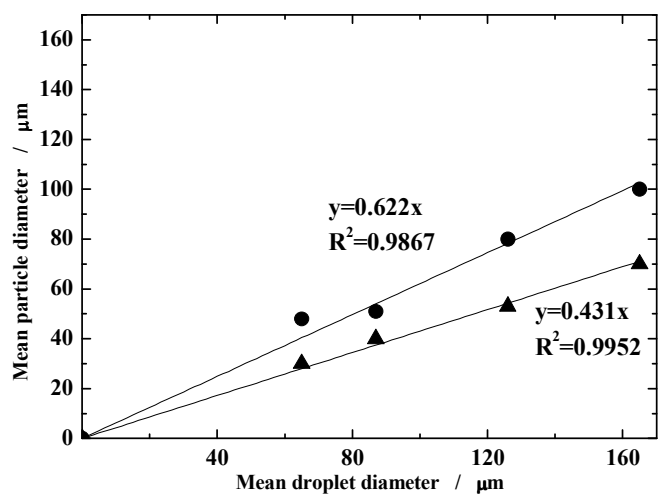

Figure 3 Relationship between the particle diameter in the resultant gels and the droplet diameter. Dispersed phase: Sodium silicate with 6 wt \% $\mathrm{SiO}_{2}$ in $1 \mathrm{M} \mathrm{H}_{2} \mathrm{SO}_{4}$. (•) Hydrogel. ( (ム) Xerogel.

The surface structure of the silica particles after calcination was imaged by SEM (operated at $2.6 \mathrm{kV}$ ) and FEG SEM (operated at $10 \mathrm{kV}$ ) and microphotographs are presented in Figure 4. The silica particles are almost perfectly round as can be seen from Figs. $4 \mathrm{a}$ and $4 \mathrm{~b}$, while the close-up of the particle surface shows a cloudy and corrugated external and internal surface morphology (Figs. 4c and 4d). The presence of pores is visible on the surface. 


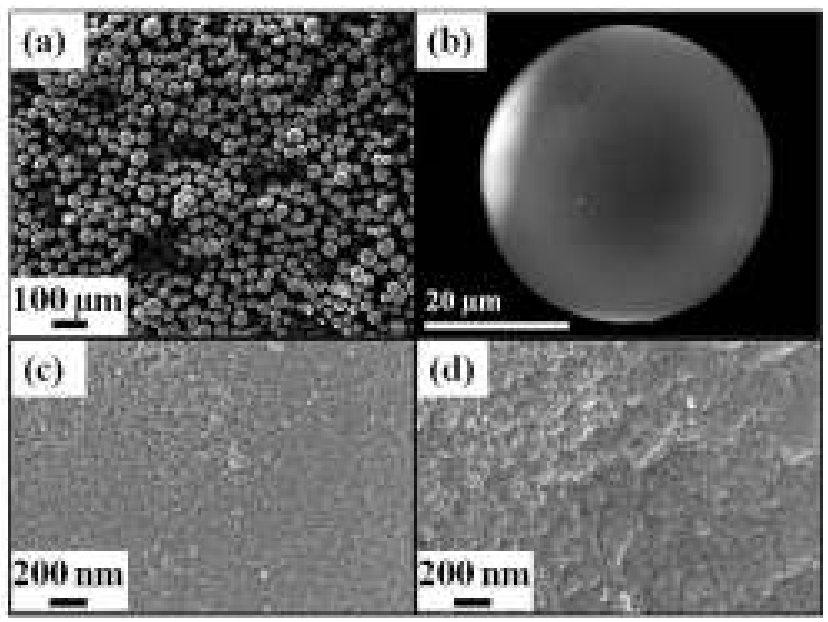

Figure 4 (a) Scanning electron micrograph (SEM) of the silica particles with an average size of 40 $\mu \mathrm{m}$. (b) SEM of a single silica sphere. (c) Field emission gun (FEG) SEM of a silica sphere external surface structure. (d) FEG SEM of a broken silica sphere.

\section{Functionalisation of silica gel and combined microfiltration/ion exchange}

The ability of functionalised particles to adsorb $\mathrm{Cu}(\mathrm{II})$ was demonstrated in a continuous flow stirred cell. The volume of the liquid phase in the cell was $140 \mathrm{ml}$ and the stirrer speed was $270 \mathrm{rpm}$. As can be seen from response curves in Figure 5, the functionalised silica particles had a higher binding affinity toward $\mathrm{Cu}(\mathrm{II})$. After about $80 \mathrm{~min}$, both nontreated and functionalized particles were fully saturated with $\mathrm{Cu}(\mathrm{II})$ and from that time the $\mathrm{Cu}(\mathrm{II})$ concentration in the effluent matched the $\mathrm{Cu}(\mathrm{II})$ content in the feed stream.

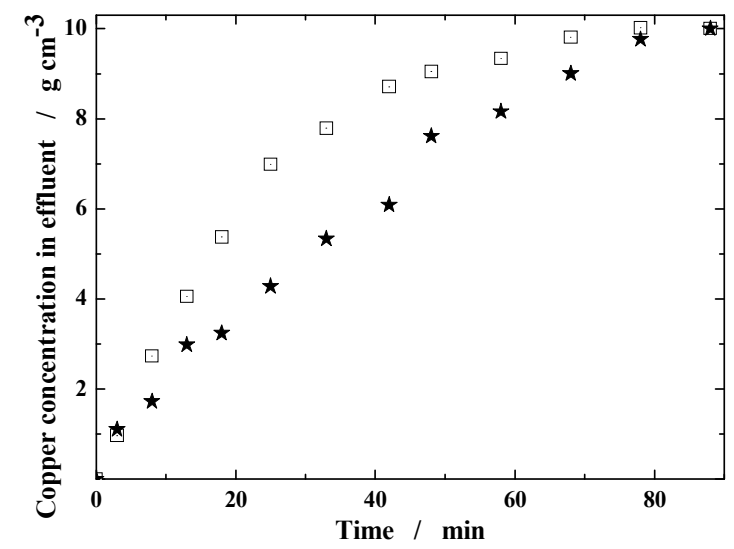

Figure 5 Chemisorption of $\mathrm{CuSO}_{4}$ on silica gel in a continuous flow stirred cell with slotted pore membrane. The copper concentration in feed stream was $10 \mathrm{~g} \mathrm{~cm}^{-3}$, the flow rate of feed stream was $8 \mathrm{ml} \mathrm{min}^{-1}$, and the particle loading in the cell was $3.5 \mathrm{~g}$. ( $\square$ ) Non-treated silica gel. ( $\star$ ) Silica gel functionalised with 3-aminopropyltrimethoxysilane.

\section{Conclusions}

Spherical silica particles with mean particle sizes controllable within a range between 30 and $70 \mu \mathrm{m}$ have been produced from inexpensive sodium silicate solution using 
membrane emulsification. The initial droplet size was precisely controlled by controlling the stirrer speed and the injection rate of the dispersed phase through the membrane and the final particle size was 2.7 times smaller than the initial droplet size. The internal porosity of the particles aged in water was $88 \%$ and $64 \%$ for the hydrogel and xerogel, respectively. Xerogel particles were functionalised with 3-aminopropyltrimethoxysilane and successfully used as ion-exchange media for chemisorption of $\mathrm{Cu}(\mathrm{II})$ from aqueous solutions of $\mathrm{CuSO}_{4}$.

\section{Acknowledgement}

This research was supported by Engineering and Physical Sciences Research Council, UK (DIAMOND project into Decommissioning, Immobilisation And Management Of Nuclear wastes for Disposal).

\section{References}

1. T. Buranda, J. Huang, G.V. Ramarao, K. Linnea, R.S. Larson, T.L. Ward, L.A. Sklar, G.P. Lopez, Langmuir 19, 1654 (2003).

2. C. Barbé, J. Bartlett, L. Kong, K. Finnie, H.Q. Lin, M. Larkin, S. Calleja, A. Bush, G. Calleja, Adv. Mat. 16, 1959 (2004).

3. T.M. Suzuki, M. Yamamoto, K. Fukumoto, Y. Akimoto, K. Yano, J. Catal. 251, 249 (2007).

4. N.J. Carroll, S.B. Rathod, E. Derbins, S. Mendez, D.A. Weitz, D.N. Petsev, Langmuir 24, 658 (2008).

5. M.K. Titulaer, M.J. den Exter, H. Talsma,J.B.H. Jansen, J.W. Geus, J. Non-Cryst. Solids 170, 113 (1994).

6. R.K. Iler, The chemistry of silica: solubility, polymerization, colloid and surface properties, and biochemistry, $1^{\text {st }}$ ed. 1979. Wiley.

7. H.P. Lin, C.Y. Mou, Accounts Chem. Res. 35, 927 (2002).

8. T. Yanagishita, Y. Tomabechi, K. Nishio, H. Masuda, Langmuir 20, 554 (2004).

9. K. Hosoya, M. Bendo, N. Tanaka, Y. Watabe, T. Ikegami, H. Minakuchi, K. Nakanishi, Macromol. Mater. Eng. 290, 753 (2005).

10. K. Kandori, K. Kishi \& T. Ishikawa, Colloid. Surface. 62, 259 (1992).

11. T. Fuchigami, M. Toki, K. Nakanishi, J Sol-Gel Sci. Techn. 19, 337 (2000).

12. M.M. Dragosavac, R.G. Holdich, G.T. Vladisavljević, Ind. Eng. Chem. Res. 50, 2408 (2011).

13. S. Brunauer, P.H. Emmett, E. Teller, AIChE 60, 309 (1938).

14. K.F. Lam, K.L. Yeung, G. McKay, Langmuir 22, 9632 (2006). 
15. M.M. Dragosavac, M.N. Sovilj, S.R. Kosvintsev, R.G. Holdich, G.T. Vladisavljević, J. Membr. Sci. 322, 178 (2008).

16. S. van der Graaf, M.L.J. Steegmans, R.G.M. van der Sman, C.G.P.H. Schroën, R.M. Boom, Colloid. Surface. A 266, 106 (2005).

\section{Figure legends}

Figure 1 Schematic illustration of: (a) Dispersion Cell containing a paddle stirrer above a disk membrane with cylindrical $15 \mu \mathrm{m}$ pores used for membrane emulsification and (b) microfiltration system with slotted pore membrane used for combined microfiltration/ion exchange experiments.

Figure 2 Droplet diameters of produced W/O emulsions as a function of rotation speed. Line represents the model prediction valid at low injection rates [15]. Dispersed phase: (ø) Sodium silicate with $6 \mathrm{wt} \% \mathrm{SiO}_{2}$ in $1 \mathrm{M} \mathrm{H}_{2} \mathrm{SO}_{4}$ injected at $350 \mathrm{~L} \mathrm{~m}^{-2} \mathrm{~h}^{-1}$. (•) Sodium silicate with $4 \mathrm{wt} \%$ $\mathrm{SiO}_{2}$ in $1 \mathrm{M} \mathrm{H}_{2} \mathrm{SO}_{4}$ injected at $350 \mathrm{~L} \mathrm{~m}^{-2} \mathrm{~h}^{-1}$. (ム) Sodium silicate with $6 \mathrm{wt} \% \mathrm{SiO}_{2}$ in distilled water injected at $1 \mathrm{~L} \mathrm{~m}^{-2} \mathrm{~h}^{-1}$. Error bars in the figure represent one standard deviation $(\sigma=\mathrm{CV} \times \mathrm{d} / 100)$ from the mean value.

Figure 3 Relationship between the particle diameter in the resultant gels and the droplet diameter. Dispersed phase: Sodium silicate with $6 \mathrm{wt} \% \mathrm{SiO}_{2}$ in $1 \mathrm{M} \mathrm{H}_{2} \mathrm{SO}_{4}$ injected at $350 \mathrm{~L} \mathrm{~m}^{-2} \mathrm{~h}^{-1}$. Hydrogel. ( $\mathbf{\Delta}$ ) Xerogel.

Figure 4 (a) Scanning electron micrograph (SEM) of the silica particles with an average size of 40 $\mu \mathrm{m}$. (b) SEM of a single silica sphere. (c) Field emission gun (FEG) SEM of a silica sphere external surface structure. (d) FEG SEM of a broken silica sphere.

Figure 5 Chemisorption of $\mathrm{CuSO}_{4}$ on silica gel in a continuous flow stirred cell with slotted pore membrane. The copper concentration in influent was $10 \mathrm{~g} \mathrm{~cm}^{-3}$, the flow rate of influent was $7 \mathrm{ml}$ $\mathrm{min}^{-1}$, and the particle loading in the cell was 2.5 g. ( $\square$ ) Non-treated silica gel. ( $\star$ ) Silica gel functionalised with 3-aminopropyltrimethoxysilane. 
(a)
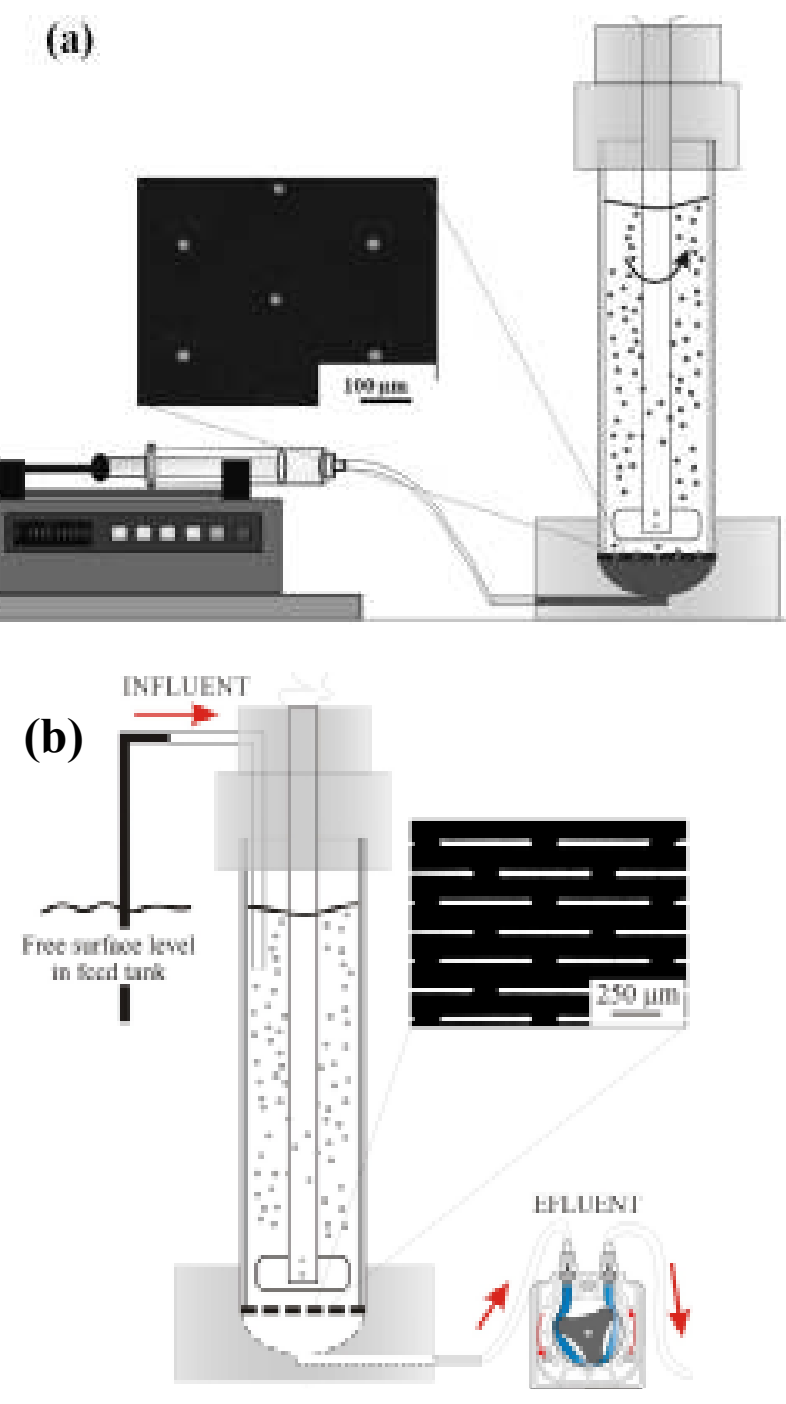

Figure 1 Schematic illustration of: (a) Dispersion Cell containing a paddle stirrer above a disk membrane with cylindrical $15 \mu \mathrm{m}$ pores used for membrane emulsification and (b) microfiltration system with slotted pore membrane used for combined microfiltration/ion exchange experiments. 


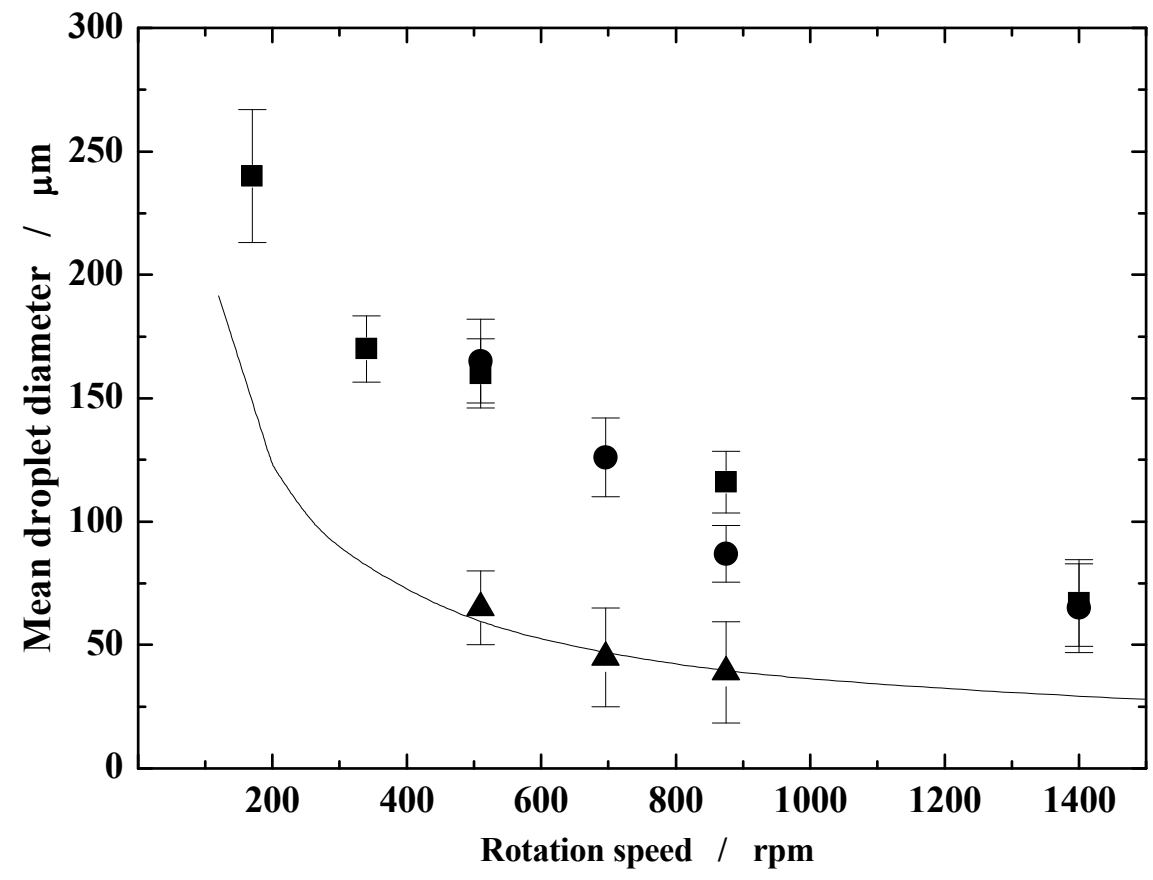

Figure 2 Droplet diameters of produced W/O emulsions as a function of rotation speed. Line represents the model prediction valid at low injection rates [15]. Dispersed phase: (匹) Sodium silicate with $6 \mathrm{wt} \% \mathrm{SiO}_{2}$ in $1 \mathrm{M} \mathrm{H}_{2} \mathrm{SO}_{4}$ injected at $350 \mathrm{~L} \mathrm{~m}^{-2} \mathrm{~h}^{-1}$. (•) Sodium silicate with $4 \mathrm{wt} \% \mathrm{SiO}_{2}$ in $1 \mathrm{M} \mathrm{H}_{2} \mathrm{SO}_{4}$ injected at 350 $\mathrm{L} \mathrm{m}^{-2} \mathrm{~h}^{-1}$. (A) Sodium silicate with $6 \mathrm{wt} \% \mathrm{SiO}_{2}$ in distilled water injected at $1 \mathrm{~L}$ $\mathrm{m}^{-2} \mathrm{~h}^{-1}$. Error bars in the figure represent one standard deviation $(\sigma=\mathrm{CV} \times \mathrm{d} / 100)$ from the mean value. 


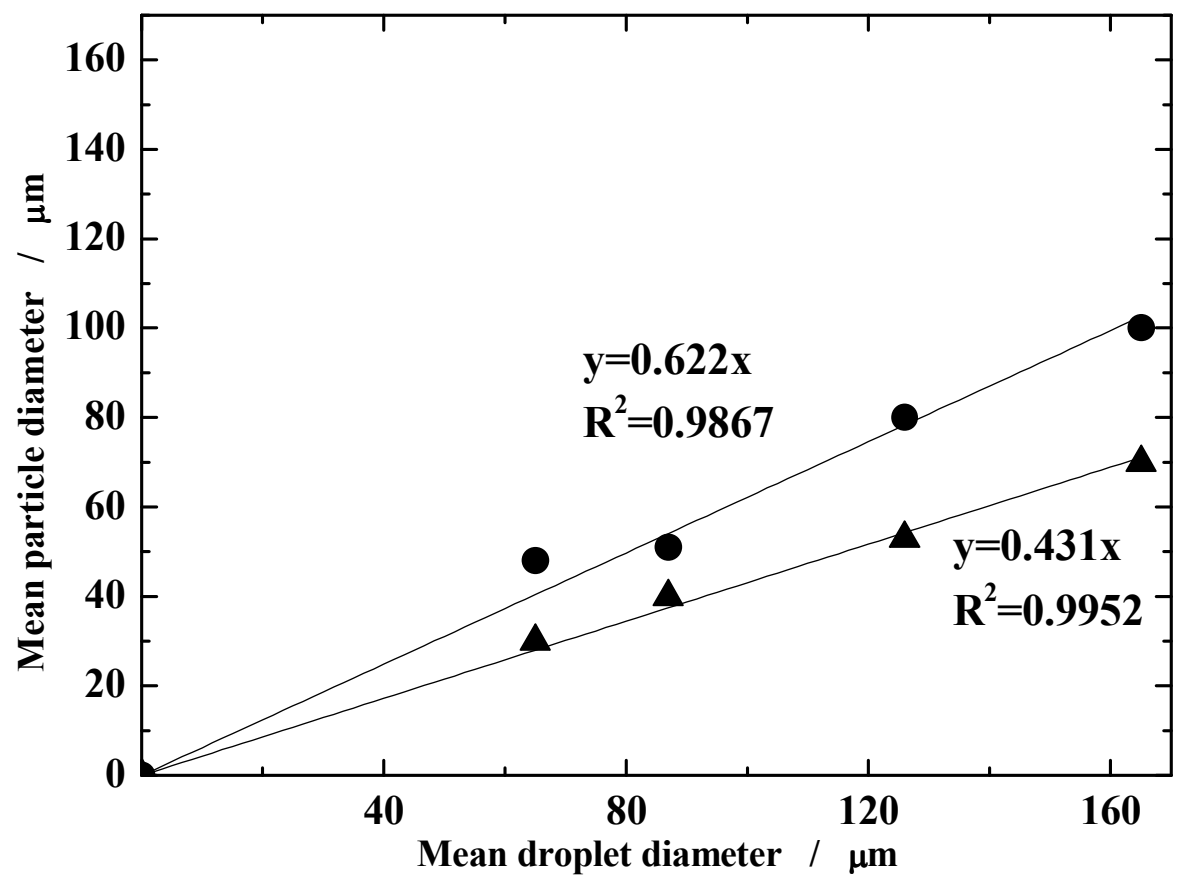

Figure 3 Relationship between the particle diameter in the resultant gels and the droplet diameter. Dispersed phase: Sodium silicate with 6 wt $\% \mathrm{SiO}_{2}$ in $1 \mathrm{M}$ $\mathrm{H}_{2} \mathrm{SO}_{4}$ injected at $350 \mathrm{~L} \mathrm{~m}^{-2} \mathrm{~h}^{-1}$. (•) Hydrogel. ( $)$ Xerogel. 


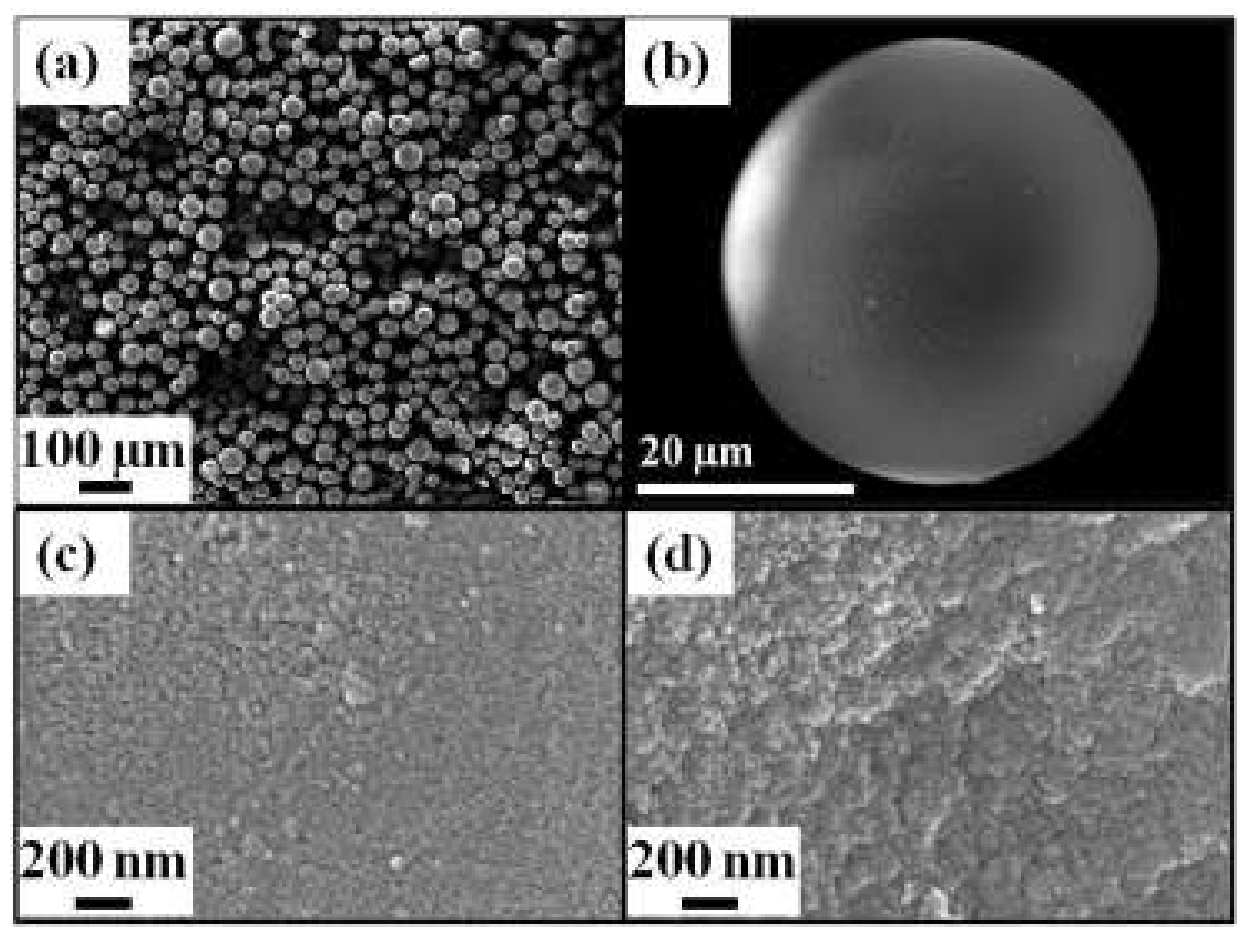

Figure 4 (a) Scanning electron micrograph (SEM) of the silica particles with an average size of $40 \mu \mathrm{m}$. (b) SEM of a single silica sphere. (c) Field emission gun (FEG) SEM of a silica sphere external surface structure. (d) FEG SEM of a broken silica sphere. 


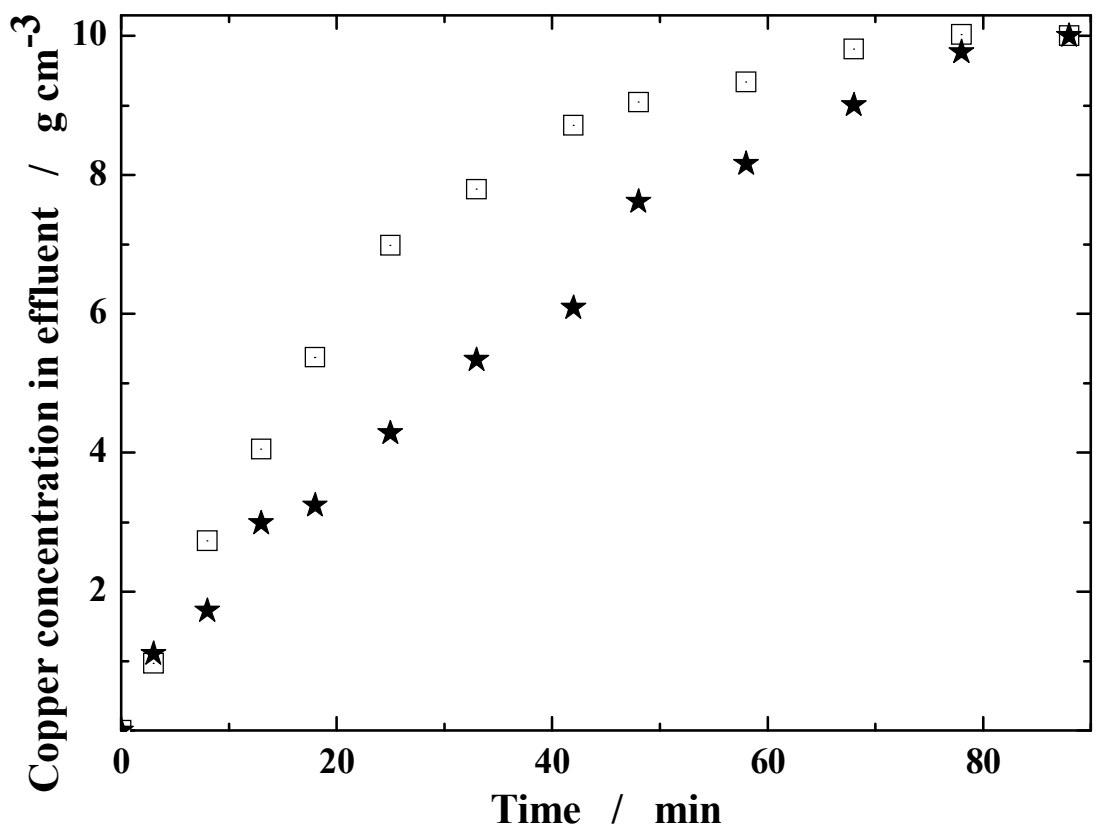

Figure 5 Chemisorption of $\mathrm{CuSO}_{4}$ on silica gel in a continuous flow stirred cell with slotted pore membrane. The copper concentration in influent was $10 \mathrm{~g} \mathrm{~cm}^{-3}$, the flow rate of influent was $8 \mathrm{ml} \mathrm{min}^{-1}$, and the particle loading in the cell was 2.5 g. ( $\square$ ) Non-treated silica gel. ( $\star$ ) Silica gel functionalised with 3aminopropyltrimethoxysilane. 